\title{
Dramatic solvent effect on the luminescence of a dinuclear gold(i) complex of quinoline-8-thiolate
}

\author{
Biing-Chiau Tzeng, ${ }^{a}$ Chi-Keung Chan, ${ }^{a}$ Kung-Kai Cheung, ${ }^{a}$ Chi-Ming Che*a and Shie-Ming Peng ${ }^{b}$ \\ a Department of Chemistry, The University of Hong Kong, Pokfulam Road, Hong Kong \\ ${ }^{b}$ Department of Chemistry, National Taiwan University, Taipei, Taiwan
}

The complex $\left[\left\{\mathrm{Au}\left(\mathrm{PPh}_{3}\right)\right\}_{2}(8-q n S)\right] B \mathrm{~F}_{4}$ (8-qnS = quinoline8-thiolate) with intramolecular gold(I)...gold(I) distances of 2.991(2) and 3.081(2) $\AA$ in two independent asymmetric units, shows a long-lived emission at $640 \mathrm{~nm}$ which is quenched by polar solvents such as acetonitrile and alcohol.

Study on the solvent and/or medium effect on the occurrence of gold(i) $\cdots$ gold(i) interactions could shed new insight into the molecular self-assembly of gold(i) atoms, which was found to give polynuclear gold(i) compounds with novel structural and electro-optical properties. ${ }^{1}$ This is particularly important in understanding the chemistry of gold(i) drugs, ${ }^{2}$ where such interaction might occur under biological conditions. Schmidbaur and co-workers had reported an interesting study indicating scrambling of the $\left[\mathrm{Au}\left(\mathrm{PPh}_{3}\right)\right]^{+}$units in a solution of the complex (8-quinolinyl)bis[(triphenylphosphine)gold(i)]oxonium tetrafluoroborate ${ }^{3}$ (Scheme 1). Spectroscopic evidence in support of the equilibrium reactions depicted in Scheme 1 only came from ${ }^{31} \mathrm{P}$ NMR spectral data of $\mathbf{B}$, which revealed two ${ }^{31} \mathrm{P}$ signals at low temperature. Herein is described the molecular structures and photophysical properties of $\left[\mathrm{Au}\left(\mathrm{PPh}_{3}\right)(8\right.$-qnS $\left.)\right]$ (8-qnS $=$ quinoline-8-thiolate) and $\left[\left\{\mathrm{Au}\left(\mathrm{PPh}_{3}\right)\right\}_{2}(8-\mathrm{qnS})\right] \mathrm{BF}_{4}$ indicating an interesting case, whereby a solvent effect on the association of the $\left[\mathrm{Au}\left(\mathrm{PPh}_{3}\right)\right]^{+}$ units through a bridging sulfur atom could be reflected by a distinct change in emissive properties.

Complexes 1 and $2 \mathrm{BF}_{4} \dagger$ were prepared by modified literature procedures 3,4 and perspective views of their structures $\$$ are shown in Figs. 1 and 2, respectively. In 1, the $\mathrm{Au}(1)$ atom is twocoordinate, but the measured $\mathrm{P}(1)-\mathrm{Au}(1)-\mathrm{S}(1)$ angle of 163.7(3) $)^{\circ}$ and $\mathrm{Au}(1)-\mathrm{N}(1)$ distance of 2.627(9) A suggest a weak $\mathrm{Au}(1) \cdots \mathrm{N}(1)$ interaction. This is different from the related

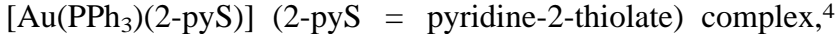
where an approximate linear geometry about the Au atom has been found [P-Au-S 177.9(1) ${ }^{\circ}$ ]. In 2, there are two independent asymmetric units, and the 8 -qnS is bonded to 2 nearly equivalent $\left[\mathrm{Au}\left(\mathrm{PPh}_{3}\right)\right]^{+}$units through the sulfur atom. The intramolecular gold(i) $\cdots$ gold(i) contacts of 2.991(2) and 3.081(2) $\AA$ are longer than those in $\left[\left\{\mathrm{Au}\left(\mathrm{PPh}_{3}\right)\right\}_{4} \mathrm{~S}\right]^{2+}$ $\left[\mathrm{Au} \cdots \mathrm{Au}_{\mathrm{av}} 2.910(2) \AA\right], 5^{5}$ but shorter than those values of $3.110(3) \AA$ in $\left[\left\{\mathrm{Au}\left(\mathrm{PPh}_{3}\right)\right\}_{2} \mathrm{SR}\right]^{+6}$ and 3.299(3) $\AA$ in $\left[\left\{\mathrm{Au}\left(\mathrm{PPh}_{3}\right)\right\}_{3} \mathrm{~S}\right]^{+} .{ }^{7}$ It is noted that the mean $\mathrm{Au}-\mathrm{S}-\mathrm{Au}$ angle of $80.6(1)^{\circ}$ lies in the range of values found in related complexes 6 which show intramolecular gold(i) ...gold(i) interactions.

The absorption spectra of $\mathbf{1}$ and $2 \mathrm{BF}_{4}$ measured in dichloromethane and in acetonitrile are shown in Fig. 3. Irrespective of the solvents, complex 1 shows an intense absorption at $386 \mathrm{~nm}$,

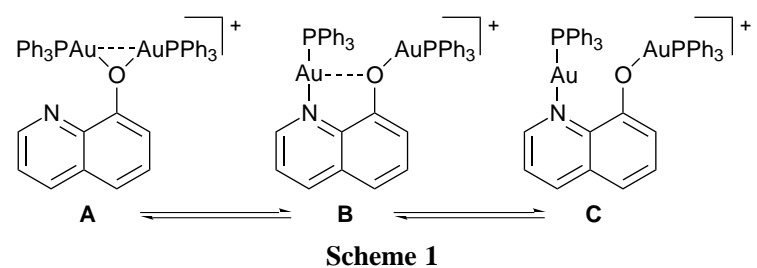

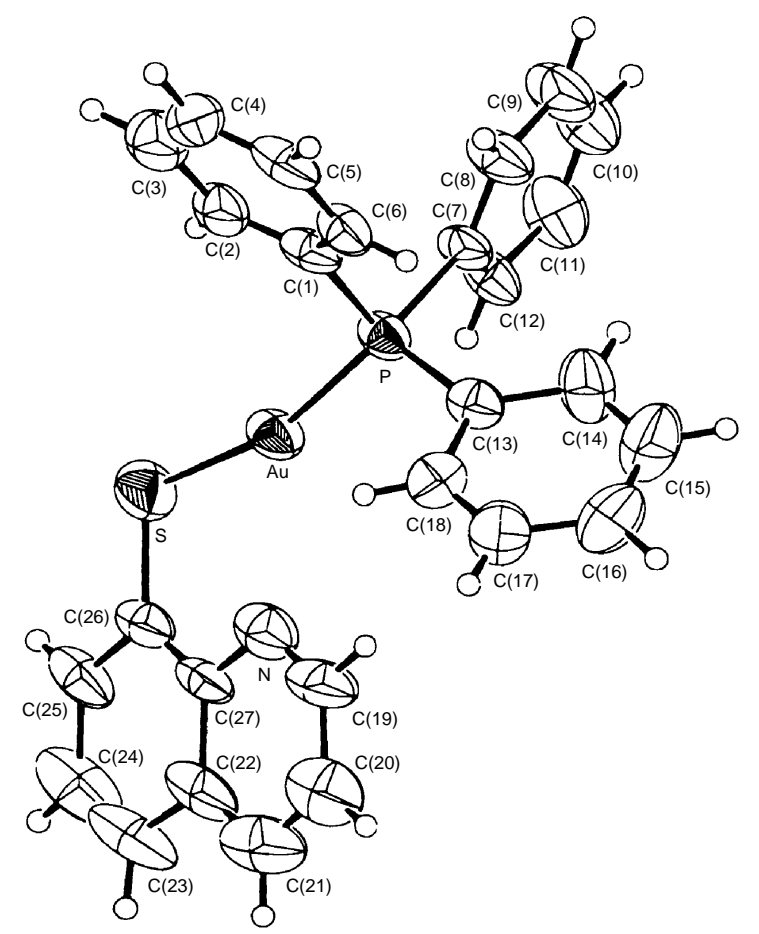

Fig. 1 A perspective view of $\left[\mathrm{Au}\left(\mathrm{PPh}_{3}\right)(8-\mathrm{qnS})\right]$ (bond lengths in $\AA$, angles in $\left.{ }^{\circ}\right): \quad \mathrm{Au}(1)-\mathrm{S}(1) \quad 2.296(8), \quad \mathrm{Au}(1)-\mathrm{P}(1) \quad 2.248(7) ; \quad \mathrm{S}(1)-\mathrm{Au}(1)-\mathrm{P}(1)$ $163.7(3)$

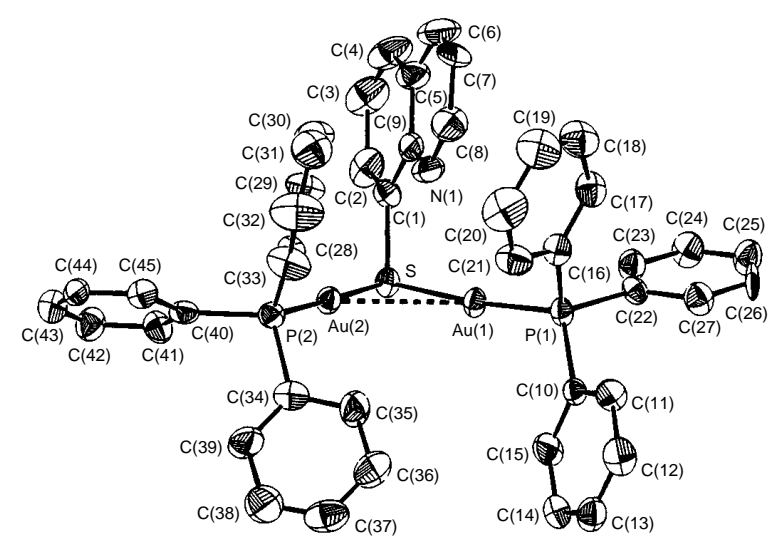

Fig. 2 A perspective view of $\left[\left\{\mathrm{Au}\left(\mathrm{PPh}_{3}\right)\right\}_{2}(8-\mathrm{qnS})\right]^{+}$(bond lengths in $\AA$, angles in $\left.{ }^{\circ}\right): \mathrm{Au}(1 \mathrm{~A}) \cdots \mathrm{Au}(2 \mathrm{~A}) \quad 3.081(2), \quad \mathrm{Au}(1 \mathrm{~B}) \cdots \mathrm{Au}(2 \mathrm{~B})$ 2.991(2), $\mathrm{Au}(1 \mathrm{~A})-\mathrm{S}(1 \mathrm{~A}) \quad 2.343(3), \quad \mathrm{Au}(2 \mathrm{~A})-\mathrm{S}(1 \mathrm{~A}) \quad 2.342(3), \quad \mathrm{Au}(1 \mathrm{~A})-\mathrm{P}(1 \mathrm{~A})$ $2.256(3), \mathrm{Au}(2 \mathrm{~A})-\mathrm{P}(2 \mathrm{~A}) 2.268(3), \mathrm{Au}(1 \mathrm{~B})-\mathrm{S}(1 \mathrm{~B}) 2.357(3), \mathrm{Au}(2 \mathrm{~B})-\mathrm{S}(1 \mathrm{~B})$ 2.351(3), $\mathrm{Au}(1 \mathrm{~B})-\mathrm{P}(1 \mathrm{~B}) \quad 2.253(3), \quad \mathrm{Au}(2 \mathrm{~B})-\mathrm{P}(2 \mathrm{~B}) \quad 2.254(3) ; \mathrm{S}(1 \mathrm{~A})-$ $\mathrm{Au}(1 \mathrm{~A})-\mathrm{P}(1 \mathrm{~A})$ 174.6(1), S(1A)-Au(2A)-P(2A) 178.6(1), S(1B)-Au(1B)$\mathrm{P}(1 \mathrm{~B})$ 172.6(1), S(1B)-Au(2B)-P(2B) 169.6(1) (A and B represent two independent asymmetric units) 


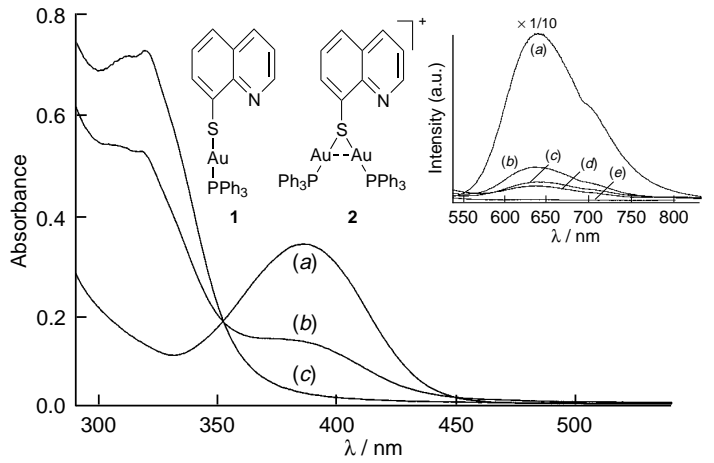

Fig. 3 The absorption spectra of $\mathbf{1}$ in $\mathrm{CH}_{2} \mathrm{Cl}_{2}(a), \mathbf{2} \mathrm{BF}_{4}$ in $\mathrm{MeCN}(b)$ and $2 \mathrm{BF}_{4}$ in $\mathrm{CH}_{2} \mathrm{Cl}_{2}(c)$; complex concentration $=9 \times 10^{-5} \mathrm{~m}$. [Insert is the emission spectra of $2 \mathrm{BF}_{4}\left(1 \times 10^{-4} \mathrm{~m}\right)$ in $(a) \mathrm{CH}_{2} \mathrm{Cl}_{2},(b)$ thf, $(c) \mathrm{EtOH},(d)$ $\mathrm{MeOH}$ and $(e) \mathrm{MeCN}$; excitation at $320 \mathrm{~nm}$ ].

which is assigned to $\mathrm{S} \rightarrow \mathrm{Au}^{\mathrm{I}}$ charge transfer (LMCT) transition. For $2 \mathrm{BF}_{4}$ there is a distinct difference in the spectra measured in dichloromethane and in acetonitrile. In dichloromethane, the complex shows an intense absorption band at $c a$. $320 \mathrm{~nm}$, which is assigned to the $5 \mathrm{~d}\left(\mathrm{~d}_{\sigma^{*}}\right) \rightarrow 6 \mathrm{p}\left(\mathrm{p}_{\sigma}\right)$ transition

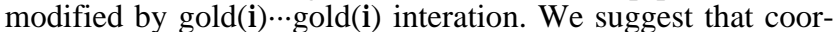
dinating the electrophilic $\left[\mathrm{Au}\left(\mathrm{PPh}_{3}\right)\right]^{+}$unit on the sulfur atom of the $[\mathrm{Au}(8-\mathrm{qnS})]$ moiety would blue shift the $\mathrm{S} \rightarrow \mathrm{Au}^{\mathrm{I}}$ transition and hence explain the apparent blue shift of the spectrum of $2 \mathrm{BF}_{4}$ from that of $\mathbf{1}$. Notably, addition of acetonitrile to a dichloromethane solution of $2 \mathrm{BF}_{4}$ increases the absorption at $c a .386 \mathrm{~nm}$ with a concomitant decrease in the absorption at $c a$. $320 \mathrm{~nm}$; the spectral changes with an isosbestic point at $352 \mathrm{~nm}$. Other solvents such as $\mathrm{MeOH}$ and EtOH also give similar spectral changes. We rationalize this finding by the following equilibrium reaction (Scheme 2).

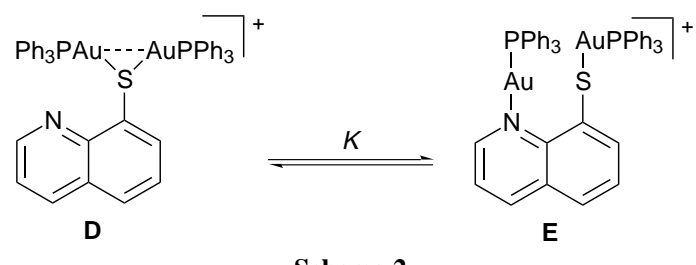

Scheme 2

Form $\mathbf{E}$ would be isostructural to form $\mathbf{B}$ in Scheme 1 and would show no intramolecular gold(i) $\cdots$ gold(i) interaction. Its absorption spectrum, therefore, is anticipated to be similar to that of 1 . Thus the spectral changes shown in Fig. 3 could be rationalized by a decrease in the equilibrium constant $K$ $(K=[\mathbf{E}] /[\mathbf{D}])$ from acetonitrile to dichloromethane. The scrambling of the $\left[\mathrm{Au}\left(\mathrm{PPh}_{3}\right)\right]^{+}$units is very fast on the NMR timescale, since the ${ }^{31} \mathrm{P}$ NMR spectrum of an acetonitrile solution of $2 \mathrm{BF}_{4}$ shows only a single peak $(\delta 34.12)$ at room temperature and even at $-35^{\circ} \mathrm{C}(\delta 32.97)$.

The reaction in Scheme 2 could also be shown by emission spectroscopy. In solution, complex 1 shows a very weak emission at $477 \mathrm{~nm}$. Excitation of a dichloromethane solution of $2 \mathrm{BF}_{4}$ gives a very weak emission at $460 \mathrm{~nm}$ and an intense lowenergy one with a lifetime of $26 \mu$ s at $640 \mathrm{~nm}$ (Fig. 3, insert).

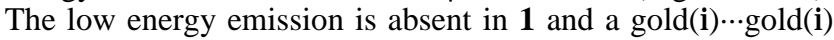
interaction is most probably responsible for it. The excitation spectrum of the $640 \mathrm{~nm}$ emission matches with the absorption spectra. The excited state is tentatively assigned to come from the metal-centred $5 \mathrm{~d}\left(\mathrm{~d}_{\sigma^{*}}\right) \rightarrow 6 \mathrm{p}\left(\mathrm{p}_{\sigma}\right)$ excitation, although mixing with some $\mathrm{S} \rightarrow \mathrm{Au}$ charge-transfer character in the excited state could not be precluded. Notably, the emission depends on solvent polarity. Polar solvents such as $\mathrm{MeCN}, \mathrm{MeOH}$, EtOH and thf were found to quench it with quenching rate constants in the order $\mathrm{MeCN}>\mathrm{MeOH}>\mathrm{EtOH}>\operatorname{thf}\left(k_{\mathrm{q}}=1.25 \times 10^{5}\right.$, $0.50 \times 10^{5}, 0.32 \times 10^{5}$ and $0.24 \times 10^{5} \mathrm{~m}^{-1} \mathrm{~s}^{-1}$ respectively). In acetonitrile, the $640 \mathrm{~nm}$ emission virtually disappears, whereas it has the highest quantum yield and longest lifetime in dichloromethane. Importantly, addition of dichloromethane to a methanol solution revives the emission. Thus, the decrease in the $640 \mathrm{~nm}$ emission in polar solvents is consistent with the UV-VIS absorption data. Because the low-energy emission at

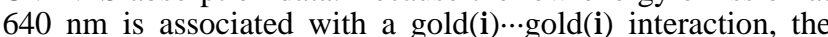
reaction of Scheme 2 may well explain the apparent solventinduced quenching of the emission of $2 \mathrm{BF}_{4}$.

We acknowledge support from the University of Hong Kong, the Hong Kong Research Grants Council, and the Croucher Foundation.

\section{Footnotes}

$\dagger$ Syntheses: $\left[\mathrm{Au}\left(\mathrm{PPh}_{3}\right)(8-\mathrm{qnS})\right] \mathrm{1}: \mathrm{NEt}_{3}$ was added dropwise to a methanol solution $(15 \mathrm{ml})$ of quinoline-8-thiol (8-HqnS, $99 \mathrm{mg})$. A dichloromethane solution of $\left[\mathrm{AuCl}\left(\mathrm{PPh}_{3}\right)\right](250 \mathrm{mg})$ was then added and stirred for $30 \mathrm{~min}$. Then $\mathrm{Ag}\left(\mathrm{CF}_{3} \mathrm{SO}_{3}\right)(130 \mathrm{mg})$ was added and the insoluble $\mathrm{AgCl}$ was filtered. The pale yellow filtrate was reduced to $c a .2 \mathrm{ml}$ to give the product (yield $=50 \%)$.

$\left[\mathrm{Au}_{2}(8-\mathrm{qnS})\left(\mathrm{PPh}_{3}\right)_{2}\right] 2 \mathrm{BF}_{4}$ : A solution of $\mathrm{Na}(8-\mathrm{qnS})$ was prepared by adding 8-HqnS $(99 \mathrm{mg})$ and $\mathrm{NaOMe}(30 \mathrm{mg})$ in $\mathrm{CH}_{2} \mathrm{Cl}_{2}-\mathrm{MeOH}(1: 1,25$ $\mathrm{ml})$. [ $\left.\mathrm{AuCl}\left(\mathrm{PPh}_{3}\right)\right](500 \mathrm{mg}, 25 \mathrm{ml}$ in dichloromethane) was added to the solution, which was stirred for $4 \mathrm{~h}$ at room temp. After addition of $\mathrm{NaBF}_{4}$ $(60 \mathrm{mg})$ the pale yellow solution was evaporated to dryness. The resulting solid was extracted with thf (yield $=45 \%)$.

+ Crystal data: $\left[\mathrm{Au}\left(\mathrm{PPh}_{3}(8-\mathrm{qnS})\right]\right.$ 1: $\mathrm{C}_{27} \mathrm{H}_{21}$ AuNPS, $M=619.47$ monoclinic, space group $P 2_{1} / n, a=14.632(3), b=10.424(1)$, $c=16.360(3) \AA, \beta=110.08(1)^{\circ}, U=2344(1) \AA^{3}, Z=4, D_{c}=1.756$ $\mathrm{g} \mathrm{cm}^{-3}$, crystal dimensions $0.2 \times 0.15 \times 0.25 \mathrm{~mm}, \mu(\mathrm{Mo}-\mathrm{K} \alpha)=64.24$ $\mathrm{cm}^{-1}, F(000)=1200$. Intensity data were collected on Rigaku AFC7R diffractometer with graphite-monochromated Mo-K $\alpha$ radiation $(\lambda=0.7107 \AA)$ using $\omega-2 \theta$ scan mode with $2 \theta_{\max }=45^{\circ} .3489$ unique reflections were measured and 1965 reflections with $I>3 \sigma(I)$ were used in the refinement. Refinement of positional and anisotropic thermal parameters for all non-hydrogen atoms (281 variables) converged to $R=0.074$ and $R_{\mathrm{w}}=0.090$. The final Fourier difference map showed residual extrema in the range of 1.89 to $-2.54 \mathrm{e}^{-3}$.

[\{Au( $\left.\left.\left.\mathrm{PPh}_{3}\right)\right\}_{2}(8-\mathrm{qnS})\right] \mathrm{BF}_{4} \cdot 0.5$ thf $2 \mathrm{BF}_{4} \cdot 0.5$ thf: $\mathrm{C}_{47} \mathrm{H}_{40} \mathrm{Au}_{2} \mathrm{BF}_{4} \mathrm{NP}_{2} \mathrm{SO}_{0.5}$, $M=1201.58$, triclinic, space group $P \overline{1}, a=14.049(5), b=17.319(6)$, $c=19.623(8) \AA, \alpha=90.09(3), \beta=108.72(3), \gamma=101.20(3)^{\circ}$, $U=4425(3) \AA^{3}, Z=4, D_{\mathrm{c}}=1.805 \mathrm{~g} \mathrm{~cm}^{-3}$, crystal dimensions $0.20 \times$ $0.30 \times 0.50 \mathrm{~mm}, \mu(\mathrm{Mo}-\mathrm{K} \alpha)=67.28 \mathrm{~cm}^{-1}, F(000)=2300$. Intensity data were collected on Enraf-Nonius CAD4 diffractometer with graphitemonochromated Mo-K $\alpha$ radiation $(\lambda=0.7107 \AA), 11585$ unique reflection $\left(2 \theta<45^{\circ}\right)$ were measured and 7758 with $I>2 \sigma(I)$ were used in the refinement. Refinement of positional and anisotropic thermal parameters for all non-hydrogen atoms (1046 variables) converged to $R=0.035$ and $R_{\mathrm{w}}=0.037$. The final Fourier difference map showed residual extrema in the range of 1.34 to -2.34 e $\AA^{-3}$.

Atomic coordinates, bond lengths and angles, and thermal parameters have been deposited at the Cambridge Crystallographic Data Centre (CCDC). See Information for Authors, Issue No. 1. Any request to the $\mathrm{CCDC}$ for this material should quote the full literature citation and the reference number $182 / 310$.

\section{References}

1 B.-C. Tzeng, W.-C. Lo, C.-M. Che and S.-M. Peng, Chem. Commun., 1996, 181; B.-C. Tzeng, K.-K. Cheung, C.-M. Che and S.-M. Peng, Chem. Commun., 1996, 1681; R.-H. Uang, C.-K. Chan, S.-M. Peng and C.-M. Che, J. Chem. Soc., Chem. Commun., 1994, 2561; S.-J. Shieh, H. Xiao, S.-M. Peng and C.-M. Che, J. Chem. Soc., Dalton Trans., 1994, 3067; D. M. P. Mingos, J. Yau, S. Menzer and D. J. Williams, Angew. Chem., Int. Ed. Engl., 1995, 34, 1894.

2 C. F. Shaw, III, M. T. Coffer, J. Klingbeil and C. K. Mirabelli, J. Am. Chem. Soc., 1988, 110, 729; M. T. Coffer, C. F. Shaw, III, M. K Eidsness, J. W. Watkins, II and R. C. Elder, Inorg. Chem., 1986, 25, 333; A. A. Isab and P. J. Sadler, J. Chem. Soc., Dalton Trans., 1982, 135.

3 A. Kolb, P. Bissinger and H. Schmidbaur, Inorg. Chem., 1993, 32, 5132.

4 P. D. Cookson and E. R. T. Tiekink, J. Chem. Soc., Dalton Trans., 1993, 259

5 F. Canales, M. C. Gimeno, P. G. Jones and A. Laguna, Angew. Chem., Int. Ed. Engl., 1994, 33, 769.

6 A. Sladek and H. Schmidbaur, Chem. Ber., 1995, 128, 907.

7 P. G. Jones, G. M. Sheldrick and E. Hädicke, Acta Crystallogr., Sect. B, 1980, 36, 2777.

Received, 20th September 1996; Com. 6/06494I 